\title{
Shakespeare Ghosting Derrida
}

Hélène Cixous

- Do you acknowledge the debt, the debit, the D?

- I do

When Jacques Derrida comes forth [s'avance] and declares himself indebted to the arch theme of translation, 'relevant', in debt and for ever insolvent, when, three times ever, he confesses to being guilty of voluntary and involuntary bankruptcy in front of [devant] translation, for all times, the admission of an amorous passion and of a flight, of a flight of passion, off passion and into passion, when he addresses to the audience this immense monologue called 'Qu'est-ce qu'une traduction "relevante"?', ' during the scene in which he is himself at once the judge, the accused, the counsel, and the whole court, he has as a double, deputy, shemblable and freer, ${ }^{2}$ a certain Shakespeare, who himself has as a delegate, mandatary and substitute, on the one hand Shylock the Jew, on the other Antonio the Christian, and also Portia the (wo)man of law, and it is as if, in this scene of scenes of mise en abyme, a question were haunting in turn each and everyone I have named here - as well as by the same stroke and coup de théatre all their doubles, whose list is endless - each separately and all together submitted to the question:Do you confess the bond? To which each of them answers in turn and simultaneously - I do. As Antonio does to Portia, so does each to the other, Shylock to the audience, likewise Derrida to Shakespeare. The current of the debt is inexhaustible.

The Oxford Literary Review 34.1 (2012): 1-24

Edinburgh University Press

DOI: 10.3366/olr.2012.0027

(C) The Oxford Literary Review

www.eupjournals.com/olr 
Do you acknowledge the acknowledgement of the debt, the IOU? Do you confirm the signed pledge, the bond, that which you owe, that because of which you are in debt or in default, indeed at fault (hence the word "confess")? Antonio's response: "I do" (a performative). Yes, I confess, I admit, I acknowledge/recognize, I confirm and sign or countersign. I do. ${ }^{3}$

I resume: when Jacques Derrida stages the drama of the unsolvable debt, therefore of forgiveness, of prayer, which rise higher than height itself, he weaves his immense philosophy of the bond by borrowing Shakespeare's characters, by using the magical guide as a help, by sublating, seasoning [relevant] his thought with that of a predecessor who asks himself about the same evils in a language other than his, wondering at the very moment when he puts the scene into play, when he acts it, performs it (in the disguised form of a lecture), do you confess the bond?, asking the question in English, a language and a question to which he owes an irreducible, untranslatable debt, for the word 'bond', bond remains and resists. And the idiom 'I do' keeps its performative value, which has no equivalent in French.

Thus Derrida 'does confess' - in English - the bond, the keep/guard [garde], the debt, the trace, the obligation but also debenture [obligation], the alliance, the note or bill, the countersignature, complicity, owing [devance]. And the bound, or French bond - of 'Ja, ou le faux-bond'. ${ }^{4}$ An elected owing. It is to Shakespeare and Company that he wishes to face owing [se veut devant].

A powerful yet light inheritance, a chosen one. He chooses Shakespeare for himself and confesses it.

At least a certain Shakespeare. Not 'all' Shakespeare, as they say. Some of the plays, a few features, a few tropes, a few words. Almost nothing, apparently. And yet...

He takes Shakespeare at his word. Not only Shakespeare naturally. The whole adventure of his thought is a hunt and chase of symptom words, cleft words that beetle over their base, clefts through which world commotions are produced. Starting with the trembling word 'I', the name for trembling, which is always at play in French (je/jeu) just as the ' $\mathrm{I}$ ' is homonymic otherwise in English. How does Derrida read a text? Whether it is fiction or drama, he will never have read the whole or part of a volume. He stitches on the other veil (as he puts it in 
Voiles [Veils]) but also pinches from it (ilpique). A genius in him guides the blind man he is, unerringly guides his hand, his beak, his quill, his stylus, his syringe towards the worm [vers le ver] or the vein. He learns a text by ear, hears the secret cry of a being of language. Besides, he only likes texts, works, corpuses which have the word, which sign, which conceal yet leave traces of the keys, which have well-kept secrets. With the word does his reading begin, that is to say, his encounter and his acknowledgement. With the adamantine flicker of a word in a sentence. He replies to Joyce with two words. He takes the words of a language, he takes a language, that is to say, a soul, an idiom within an idiom, at its words. It is the principle.

$[\ldots]$ the word (for the word will be my theme) [...] interests me, I believe I can say that I love it, that's the word, only in the body of its idiomatic singularity, that is to say, where a passion for translation comes to lick it $[\ldots]^{5}$

In a word, no more of one word / more than one word [plus d'un mot], this is what inclines him towards a kind of literature with words.

And, naturally, Derrida enjoys himself when he writes and signs this declaration of conditional love to the word, of love therefore for the word - (that is to say, supposedly for the double unity which empowers language to speak, for what he often calls the vocable) — in general - by simultaneously subjecting the word, the subject, love to its condition as a French word - he does not love the word, he only loves it but to distraction, where and when the word itself furiously resists the attempt to translate which however it itself calls for, he declares his passion first to the word, au mot — to the 'homoword' [au mot homo], to the word with homonymic resources, which plays in and with itself, by itself, pivots, blinks so well that it always eludes the claws of the desire to translate, and does not let itself be clawed (back).

Je viens ici d'écrire un paragraphe en français intraduisible. I translate: I have just written an untranslatable paragraph in French here, which I dedicate to Jacques Derrida. For it is when the mouth starts opening, when a tongue licks the word on the other's tongue, that Derrida approaches the shores of the Shakespearian idiom. Derrida loves in 
French Shakespeare's English. His dream is to take Shakespeare at his English word. He would like to see him taken (with it) [épris, pris], a captive lover (and the other way round). And, after all, nothing will have moved and inspired him more than this or that sublimely philosophical sequence, this 'mercy seasons justice' which happens to be speaking French Latin in English. Three words whose challenge not even a seasoned translation into French but one into the Derridean idiom will be able to rise to. And when, on the occasion of a marvellous encounter between several languages around cross-borderwords [mots passe frontières], Derrida will expand on the history and poetics of his coinage, which the world inherited, of the word relève in French, in order to translate Hegel's German Aufhebung, by spicing and seasoning it with innumerable connotations from convergences and equivalences between the domains of flavour and taste - that's what you call 'making a meal of it'! — with the analytic work of the negative, that is to say the very operation of deconstruction which consists in speaking in more than one language within one single language, like Shakespeare.

Similarly Derrida opens himself to Genet, Joyce, Celan, Shakespeare, Blanchot, etc in the breath of a shibboleth.

Two words or four words. Thus:

— Rose! — He war. — Die Welt ist fort. — Viens!

- Mercy seasons justice. - What's in a name?

— The play's the thing...

This dazzling economy, this stroke of luck [coup de veine], these meaningful blood samples [sang/sens], this poetic practice of the philosophical, are the prophetic weapons and tools of 'psychoanalysis' before-the-letter as it manifests itself in opening the inaugural scene of the unconscious, that of the play within the play in Hamlet. To make truth while resorting to dramatic metaphor, to produce effects of unveiling without tearing the veil, is the very art of the theatre-withinthe-theatre which Shakespeare will have brought to incandescence: through evocation, through condensation and displacement, through spectral figuration, to make the trace of the secret spring to light. This operation requires only a few words in a textual ocean, but powerful, piercing words, capable of shaking a wall of repression. How many 
words does Hamlet need to make Claudius fall? - A speech of some dozen or sixteen lines (2.2.573-74).

And how many to 'purify' Gertrude's heart, that is to say, to analyse it, separate 'the worser part of it' from the less bad? - I must be cruel only to be kind (3.4.178).

Doesn't this kind cruelty blaze the trail which will lead to Etats d'âme de la psychanalyse, ${ }^{6}$ some four centuries later?

\section{Relevances Redevances (IOU's) - 'Jacques Derrida before the letter'}

As if there were an eleventh commandment for him: 'thou shalt not translate the being named Shakespeare'.

Jacques Derrida's great lecture on translation, 'Qu'est-ce qu'une traduction "relevante"?', begins with the announcement of his giving up on translation, in this case of a fragment from Shakespeare.

I quote the quotation, the one quoted and the one who quotes:

" "Then must the Jew be merciful"

(Je ne traduis pas cette phrase de Portia dans Le Marchand de Venise)', he says. I translate: I do not translate this sentence of Portia's in The Merchant of Venice.

How not to allow an analytic curiosity to prevail upon us. This case of non-translation is so beautiful, so provoking, so enigmatically promising. Here are a few questions:

1) Why does $I$, Jacques Derrida, not translate, what, from Shakespeare? 'I do not translate this sentence', he says. Is it 'this sentence' among all the sentences? A sentence of Portia's? A sentence from The Merchant of Venice? What is there in this sentence? Who pushes Derrida to make such a declaration of non-translation? Is it 'the jew', or 'must the jew' or 'be merciful' which opposes to Jacques Derrida an objection to translation? Or suggests that Jacques Derrida, a Jew, be 'merciful' with the object, the quoted sentence, that he leave it alone in his own language? What does not-to-translate mean? Maybe I does not want to 'translate', to transport, to relever (elevate, relieve) Shakespeare? Or else he wants to leave Shakespeare to Shakespeare, to keep him in infinity, in the infinities of his language, I mean the Shakespearian idiom, this kind of unique example of English. Just as deep within himself, the kind of Jewish Shakespeare from Algeria that he is, the 
giant monolinguist of a French language with which, within which, against which, through which he soars [s'élève], higher and stronger than any other magnificent inhabitant, would perhaps wish to be left to speak in his own language, and that people come and listen to him in this tamed, yet still wild language.

One must imagine the secret passion, the modest and jealous admiration of the poet within Jacques Derrida playing on the towers and tropes [tours] of Babel, for the greatest among all these 'finite divinities" who cannot make or create one sentence, two words, without them being powerfully, inimitably signed. In truth, everything he says and credits [dit, crédit] on the subject of Joyce, as he crowns him last of the gods in 'Ulysses Gramophone', is like the substitute confession of the supremacy and superpolymathy of a Shakespeare. Just like Joyce, before Jacques Derrida the great anticipator [prévenant].
[...] nothing can be invented on the subject of Joyce. Everything we can say about Ulysses, for example, has already been anticipated, including, as we have seen, the scene about academic competence and the ingenuity of metadiscourse. [...] Everything that happened to me, including the narrative that I would attempt to make of it, was already foretold and forenarrated, this unusualness being dated, prescribed in a sequence of knowledge and narration: within Ulysses, to say nothing of Finnegans Wake, by a hypermnesis machine capable of storing in an immense epic work, with the Western memory and virtually all the languages in the world including traces of the future. Yes, everything has already happened to us with Ulysses and has been signed in advance by Joyce. ${ }^{8}$

(Yes, everything has already happened to us before Ulysses with Hamlet, in other words Hamletulysses, and has been signed in advance, before everything, by Shakespeare.)

Yes, when, mocking at himself and denouncing himself as he denounces all the other 'scholars' with him, all overpreprogrammed by the letter of Ulysses, he confesses, as if boasting, a 'terrified desire' to belong to the Joycean 'family', as a bastard son, a place that fits him like a glove, he is but repeating the painful, complex scene of his genius, as a bastard or circumcised genius, unhappy to be born on the 
margin of legitimacy, happy in the secure knowledge in advance that he won't ever be able to ascertain any principle of truth or legitimacy. Now the torments of this terrified desire to belong without belonging, the anger and suffering about being doomed to the dislocation of legitimacy, to the questioning of the signature which does sign [qui fait signature], have always already been depicted in all their essential as well as accidental guises by Shakespeare. The inadequacy of the subject to himself, internal dissociation, repudiation, abdication, the innumerable figures of internal and external banishment, the hunt, the fall, blinding, the fault, all these commotions strike Shakespeare's royal people, from feast to defeat, from Antony to Cleopatra, from Romeo to Juliet from Lear to Cordelia from Oberon to Titania from Julius Caesar to Richard II, 'text over text', the apparently anachronistic accident punctuates apparently diverse destinies, in fact all submitted to the mutual encounter between desire and countertime:

What happens to Romeo and Juliet, and which remains in effect an accident whose aleatory and unforeseeable appearance cannot be effaced, at the crossing of several series and beyond common sense, can only be what it is, accidental, insofar as it has already happened, in essence, before it happens. The desire of Romeo and Juliet did not encounter the poison, the contretemps or the detour of the letter by chance. In order for this encounter to take place, there must already have been instituted a system of marks (names, hours, maps of places, dates and supposedly "objective" place-names) to thwart, as it were, the dispersion of interior and heterogeneous durations, to frame, organize, put in order, render possible a rendezvous: in other words to deny, while taking note of it, non-coincidence, the separation of monads, infinite distance, the disconnection of experiences, the multiplicity of worlds, everything that renders possible a contretemps or the irremediable detour of a letter.'

The sovereign is not sovereign. The subject is the object of an interminable internal argument, the object and the place.

Not at home in his place. Not at the right time. A fateful belatedness precipitates each into a cruel ill-coming [malvenance]. To sleep, perchance to wake too late. Not only is the Jew always already for ever an anachronism, in this 'Venice' which, till Proust still, has occupied 
the phantasmatic place of Delphi, seat of the fair-haired gods, and where the stranger, should he be a victorious general like Othello, not only has no chance of 'lasting' but also owes 'mercy' to God the Christian. Or to the justified Christian.

'Then must the Jew be merciful'?

- That's how it is, then, the Christian may not (want to) forgive?

Richard II does not forgive, and neither does Hamlet by the way, nor Portia, and in this immense literature of the unforgivable deployed by Shakespeare, one is hard put to find a scene of forgiveness. Besides, rare though these may be, they are utterly gripping. I am thinking of the one coming only near it but without the word for it, by disuniting and reconnecting Brutus and Cassius (Julius Caesar, Act 4, scene 3), and of course of the one which brings Lear down at Cordelia's knees. (In fact, in both these cases, anger and tenderness are affects inherited from the mother.) Then, says Jacques Derrida, annoyed, it is always the Jew that has to be merciful? It is therefore always 'The Jew', this concept that precipitates the singular towards the race, the mass which must be twice offended? Offended as he is by the fault of a Christian. Insofar as he is forced, almost pushed, doomed to forgive. And therefore never in the place of the one who is pardoned? Here we must re-read this sublime pleading from the most righteous of philosophers who (in an immense, painful parenthesis spanning over ten pages) analysed in the most powerful way bad faith in the use of Christian faith and the theme of pardon misappropriated by a cunning which finds in Portia Shakespeare its first and last mouthpiece. For such is the force and the militant, mercenary conviction of this prosecutrix with a double male/female power and double twist of slyness, to which Shakespeare lent his formidable genius for casuistry, that Portia's speech finds itself carrying John-Paul II's utterance in 1998 with the same frightening competence. And one can expect Derrida's sublime deconstructive refutation to have to return to the fight for the centuries ahead of us. I will only cite here, as a token of admiration, a few lines from this exceptional moment in the work of Jacques Derrida, in which he stands up against the false prophets as the incarnation of philosophical Virtue which only complies with its aim of unconditional Justice: 
In saying all the bad things that can be thought of the Christian ruse as a discourse of mercy, I am not praising Shylock when he raises a hue and cry for his pound of flesh and insists on the literalness of the bond. I analyze only the historical and allegorical cards that have been dealt in this situation and all the discursive, logical, theological, political, and economic resources of the concept of mercy, the legacy (our legacy) of this semantics of mercy - precisely inasmuch as it is indissociable from a certain European interpretation of translation. ${ }^{10}$

Three remarks:

1) The force developed by Derrida can be measured by that of his masked predecessor.

2) It is also because all this verbal sparring would take place at the theatre, as if it were under the non-responsible roof of literature, there where, in this place where the characters' infinite freedom prevails, from which the author can demarcate themselves as they please, that Derrida can in turn express his indignation most vigorously, giving his diatribe a giant's voice within the theatrical enclosure of his parenthesis. After all, the opponent whom Derrida topples in the dust is nobody made of flesh and blood which the blows could hurt; it is the character Portia.

3) Another Shakespeare can be glimpsed through Derrida's reading, a Spectre of Shakespeare who would have been a great philosopher if, unlike Derrida for whom philosophy gets the better of literature, literature had not transported him into illyriterature beyond Good and Evil.

\section{Derrida may/be Shakespeare}

The 'great philosopher' Jacques Derrida proceeds like the 'great philosopher' whom Nietzsche speaks about in Beyond Good and Evil. One must read, says Nietzsche, says Jacques Derrida, the 'great philosophers' umgekehrt, in the back, from the back, from behind, above their backs, backwards. Each great philosophy will have been in a way the confession of its author and a kind of involuntary memoir. When a great philosopher (let's say Nietzsche, let's say Jacques Derrida in Nietzsche's back therefore) produces a great philosophy, he writes his 'memoirs' in secret. By saying 'great philosophy', Nietzsche suggests, Jacques Derrida suggests in his back, that only the great philosophies are autobiographical testimonies. Mediocre philosophers talk only of 
philosophy. Paradoxically great philosophies are great because they give away their signature. Like the martyr confessing their philosophy, the subtle movement of Derrida reading Nietzsche and slipping into this reading, towards the martyr whom he confides in more and more frequently, advancing in time, confessing in the other's confession, making philosophy out of his anxieties, weaving philosophical anxiety, relentlessly denouncing what he calls 'the verdict'.

Just as, according to legend, Shakespeare allegedly entrusted the mourning of his only son, Hammet, who died an early death, to the play called Hamlet, just as legend thinks it can detect in Elsinore's graveyards the ghost of a little boy whose grave and coffin remain without a specific address, just as there is nothing forbidding us to think or proving that the poet's pain is at the origin of the repeated massacres in Hamlet, the father falls with the son, the son follows the father into the grave, there is no greater pain for a parent, says Freud, than to see a child die, one can never find consolation for it, he says, as Derrida pointed out and noted in 'Freud's Legacy', ${ }^{11}$ so does the note of disconsolateness begin to ring in the work of Derrida, a child is going to die, a child is dead, distinctly from the end of the 1980s onwards, or else it was already the case in Glas - the bell [glas] already tolled, for such and such a child, from now on regret or grief, the repeated lamentation of Derrida weeping over the child, his own, and in each and every child, the child he himself is, increases ceaselessly, spreading his anxiety and his weeping from one text to another up to the last. The world is full of dead children, of little murdered princes, of widowed sons and orphaned fathers. And what about Cordelia, it might be said, the third one, the one and only? She is not a son now, is she, it might be said. Cordelia is not a son, nor a daughter either. She is the mother of the oldest and most miserable of the sons.

There is nothing impersonal about this one living creature who is all the more living since he is expecting death. However, except for a few features of reference in 'Circumfession' or in Counterpath, his autobiography can be traced in the minute, gripping portrait of a soul which the Derridean corpus sketches in the dazzling series of veiled selfportraits whose scenes of tribunal, of war, of graveyard, of funeral wake are crowded with his prophetic, premonitory figures, the same scenes as the ones in which Shakespeare, with a bare heart under the gown or the suit of armour, appears at the Perpetual Sacrifice. In the guise of the 
beast and of the Sovereign, god as executioner and victim, Shakespeare Derrida passes as undecided and undecidable as Hamlet held back on the brink of the grave and speaking for the dead, speaking about the dead to the half-dead. As shaking as Shakespeare, apostrophizing himself, Derrida apostrophizes, stuns himself, unknowingly calls himself Elijah: Elie, Eli! the figure of self-elision, of the elision of the self, or of the ego, insofar as Elijah eloigns himself, recedes in the distance, distances himself from himself in the desert, furious, alone, but speaking like the magnificent, irascible Timon, forever out of his house. Insofar as Jacques remains (in his house) [demeure], incessantly comes back to his house, goes away in order to return to the house theme. Housing away [maisonne]: no house without a door, opens itself, a door through which the instituted wound, the presumed within opens itself to the presumed without. Housing away: no house without a family. House opens to the possibility that it opens or shuts, house of Cordelia, of Edgar, houses of hostipitable hospitality of Macbeth, of Regan, of Richard II. Violent, violated house. Somebody from the outside, a stranger, is received and driven out. Somebody from the inside is the inside stranger, the poison in the house, Iago, Edmund, Richard III. House-and-banishment is their obsessive theme, Das nicht $z u$ Hause sein, the traumatic experience of the not-at-home at-home. One day, in 1585, in 1942, ${ }^{12}$ I am no longer at home, although I was King yesterday, I Richard II banished the others yesterday, today I am undone and banished, I divest myself [dépouille], and all of a sudden die Welt ist fort I am done for [fichu] or else you're the one done for, my father, my son, my native land, my mother tongue which is silenced and kills me [qui est tue et me tue]. The affect of Unheimlichkeit, where the molten fires of anxiety surge upwards where trust was insidiously betrayed, is the same blood, the tears of the circumcised one in 'Circumfession', as well as those of the seriously wounded Athenian. It is there, at the gaping edge of the wound, when trust is forever divided, that the 'Maybe', the dangerous Maybe, heaves an anxious sigh. Shakespeare, Derrida, philosophers of the 'maybe', that is of supreme risk. Everywhere the disturbing song of the Maybe, Perchance, Vielleicht can be heard. Our characters are poised on the brink of the abyss of time, exposed to the absolute risk of the maybe as the irreducible modality of thought and of the opening to the future-to-come [avenir]. Good or bad, beyond good 
and evil, the character blindly takes the supreme risk, he is taken by risk, he cannot do otherwise but be the hero of the maybe. 'Ravisher and ravished, what he would but would not', doomed to what comes, he is today the ghost of tomorrow, the wind by Hippo's rocks or what you will, the sea's voices, the warm salted blue Mediterranean voice the cold silver grey mother's voice, 'a voice heard only in the heart of him who is the substance of his shadow, the son consubstantial with the father'. ${ }^{13}$

Who? The son of the father son of the son maybe, Derrida father and sons, He Who Himself begot, and Himself sent himself and himothers between His self and others. The son of the mother father of the daughter on the mother's side. Maybe the daughter mother of the child father at the knees of Cordelia Georgette Esther. ${ }^{14}$

'Maybe' or the Un-beyond the contraries, to die and maybe not to be dead, to die, who knows, to lose one's life, and maybe not to meet one's death? Perchance:

To die, to sleep.

To sleep, perchance to dream. Ay, there's the rub,

For in that sleep of death what dreams may come

When we have shuffled off this mortal coil

Must give us pause. There's the respect

That makes calamity of so long life,

For who would bear the whips and scorns of time,

$$
\text { [...] }
$$

Who would these fardels bear,

To grunt and sweat under a weary life,

But that the dread of something after death,

The undiscovered country from whose bourn

No traveller returns, puzzles the will,

And makes us rather bear those ills we have

Than fly to others that we know not of?

(Hamlet, 3.1. 64-70, 76-82)

Mad, reasoned speculation of Hamlet wondering, Hamlet to whom Hamlet's question is submitted by Hamlet, a strange, madly reasoned bet on dying and uncertain, necessary, impossible death, pursued as 
if, then, at the time of Act 3, Hamlet, the one who divides (himself) here, had not already received an answer to his call, as if his father were Ghost for nothing, as if the Ghost's Testimony counted for nothing, as if Hamlet the father had un-died of death, uselessly...

But maybe this is because no dead person, no death has anything to teach us. Chaque fois unique la fin $d u$ monde. ${ }^{15}$ Each being to his own death. Each and everyone dies and meets death for the first time. Philosophizing teaches us nothing about death, nor about dying, nor how to live. Anxiety begins again eternally for the first time, there is no ego before this twist [torsion], before the experience of the impossible Unheimlichkeit which opens it by inscribing the door [porte], always hidden, which bears [porte] it yonder, to the unknown and not here. Nobody interrupts Hamlet's solitude. Hamlet who? I mean Hamlet Derrida.

The Ghost does not arrive. Poor Ghost. However much he signals, sends innumerable letters, riddles the whole text of the Ghost with sighs in $\mathrm{O}$, makes bubbles, leaves empty traces in the Shakespearean fabric, this marvellous and tragic screening [criblage], this maculation in white that no seasoned translation will ever be able to live up to [relever] for the Ghost, no matter how Danish he may be, is in truth a ghost who haunts the soul of William Shakespeare, impacts his dreams in English. $\mathrm{O}, \mathrm{O}, \mathrm{O}, \mathrm{O}, \mathrm{O}$ - the rest of $(\mathrm{Gh}) \mathrm{o}(\mathrm{st})$, the letter of the father. Like this - 'O Ghost, host if thou hast any sound or use of voice speak to me!' - they do not manage to reach [n'arrivent pas à arriver] the ear of the heart, nor on time.

It is for the Ghost that the Time is at the Out of Jointest [sic]. He is the untimely itself. 'What is coming, in which the untimely appears, is happening to time but it never happens on time'. ${ }^{16}$ There is no time for The Ghost. There is neither Time nor World. Die Welt ist fort? Alas, poor mole. And nobody to carry you. A bit of smoke, some ashes, nobody to gather them. How you disappeared at the end of this story! When did he disappear then? Never to come back? On which word, which last word, did he vanish? You remember? At the end of which scene? In the middle of which act, behind which veil or sail [voile], curtain, visor, door? No witness for the witness of impossible death? One cannot imagine anything more ghostly. The Ghostest ghost, the lostest ghost, o, o, o, o, oblived, oblivioned. Without farewell. 
The revenant has not come back, he won't come back any longer. And nobody to say 'I can no longer remember who was urging me to remember I no longer know what.'

How short Hamlet's life is, even shorter the duration of the thing.

\section{Hamlet, or the Sighing Tragedy}

It is Horatio the analyst who wonders in which language one should address a ghost so that the ame en peine (lost soul), as one says in French, may give evidence. As we know, there is a whole protocol not at our disposal in order to establish communication. Which does not mean that 'It' (the Apparition, the thing) does not express itself. It knows full well how to get across what it does not want.

How does a spectre speak?

Like a Speaktre, at least the whisper goes so

Go go go Ghost

Speak to me

If thou hast any sound or use of voice

Hear-see the canticle of Nought the Ghost in a hundred and forty O's and thirty sighs:

\section{HoRATI무}

That can I;

At least, the whisper goes so. Our last king,

Whose image even but now appear'd to us,

Was, as you know, by Fortinbras of Norway,

Thereto prick' $\mathrm{d}$ on by a most emulate pride,

Dared to the combat; in which our valiant Hamlet-

For so this side of our known world esteem'd him-

Did slay this Fortinbras; who by a seal'd compact,

Well ratified by law and heraldry,

Did forfeit, with his life, all those his lands

Which he stood seized of, to the conqueror:

Against the which, a moiety competent

Was gaged by our king; which had return'd

To the inheritance of Fortinbras,

Had he been vanquisher; as, by the same covenant, 
And carriage of the article design'd,

His fell to Hamlet. Now, sir, young Fortinbras,

Of unimproved mettle hot and full,

Hath in the skirts of Norway here and there

Shark'd up a list of lawless resolutes,

For food and diet, to some enterprise

That hath a stomach in't; which is no other-

As it doth well appear unto our state-

But to recover of us, by strong hand

And terms compulsatory, those foresaid lands

So by his father lost: and this, I take it,

Is the main motive of our preparations,

The source of this our watch and the chief head

Of this post-haste and romage in the land.

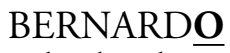

I think it be no other but e'en so:

Well may it sort that this portentous figure

Comes armed through our watch; so like the king

That was and is the question of these wars.

\section{HoRATI므}

A mote it is to trouble the mind's eye.

In the most high and palmy state of Rome,

A little ere the mightiest Julius fell,

The graves stood tenantless and the sheeted dead

Did squeak and gibber in the Roman streets:

As stars with trains of fire and dews of blood,

Disasters in the sun; and the moist star

Upon whose influence Neptune's empire stands

Was sick almost to doomsday with eclipse:

And even the like precurse of fierce events,

As harbingers preceding still the fates

And prologue to the omen coming on,

Have heaven and earth together demonstrated

Unto our climatures and countrymen.-

But soft, behold! lo, where it comes again! 


\section{Re-enter Ghost}

I'll cross it, though it blast me. Stay, illusion!

If thou hast any sound, or use of voice,

Speak to me:

If there be any good thing to be done,

That may to thee do ease and grace to me,

Speak to me:

(Hamlet, 1.1.78-129)

(It was about to sp(eak) when the cock crew)

St! Sp! Lisp lisp Cock!

To whom does the Speakter speak, to whom not? To whom does Ghost unspeak?

With all its ghostly hope Ghost addresses Ho Ratio, addresses the analyst who will have been the listener, the witness, of Hamlet and Hamlet, the one to whom Shakespeare entrusted the role of the ear and receptacle for words, words, worse [mots/maux], the eloquent silence of what suffers, of those who suffer, the inaudible speech.

It is to Hamlet that Hamlet speaks, according to the principle of ventriloquy which Derrida described in The Gift of Death. Hamlet in Hamlet asks Hamlet to give him death, that is to say, the impossible twice impossible, by way of the gift and by way of death. Never could one imagine greater double suffering.

What does Ghost suffer from? From an impossible necessary death. From being, through the supreme cruelty of the crime committed by Claudius, more than several times committed by the brother, the friend, the fellow creature [semblable], several times murdered, from being without being, dead without death, dead deprived of death, dead in abeyance, letter in sufferance, poste restante, letter arrested in an endless sleep, frozen in the imminence of the impossible dying without life without death, the impotent witness of its own disjunction, ${ }^{17}$

from being disjointed, from being struck with disjunction, from being the disjoiner of himself, of his son in him and of himself in his son, between Hamlet and Hamlet, Hamlet. 


\section{The gift of the ghost}

He has recognized someone who, like him, appears obsessed by ghosts and by the figure of the ghost and by its names with their troubling consonance and reference (Geist, Gespenst). [...] I am describing then this feeling: that of a Marx obsessed, haunted, possessed likelas Stirner, and perhaps more than him, which is even harder to take. ${ }^{18}$

I am haunted by myself who am haunted, etc.

Why Shakespeare?

Because he is the master, the king, the Lord of the Ghosts. Because he does not exist, he can be more easily incorporated than others with whom Derrida weaves an alliance (Blanchot for instance)

but whom he cannot poach [voler] (as he says about Marx and Max Stirner), poach, approach and broach [avoler, avaler] so easily

Shakespeare is the name of a corpus, of an infinite, unlimited body without ego, without an absolutely identifiable owner, it is the name of the skull which had a tongue which is the whole tongue, Hamlet Derrida gathers him in the graveyard which houses [où demeurent] the archives of his innumerable melancholy affects. Because he mostly loves the great solitaries, those whose step hesitates [marquent le Pas] at the borders, the great fatherless or motherless orphans, Celan, Genet, Blanchot, Defoe

Derrida has always pitied the dead for being so very dead and the living for being so close to death so quickly. And now he has recognized someone who, like him, appears obsessed by ghosts and by the figure of the ghost. If he has recognized him, it is insofar as, likelas him, he recognizes himself reflexively, he recognizes himself in the one who like a revenant comes back before him, like/as him. That haunted one, that Will, will even have managed to show the universe what man cannot see.

He drew from the night, in which they are tolerated and feared, the daytime prohibitions, the revenants who step beyond the portals of death, and during his reign, those that had been kept at a distance since that time, doomed to the cave, the actors that play in us for us our roles as executioners and victims, he invited all this rejected population to come and share the stage where the madness of the day is unleashed. 
Someone who is besieged, like him, by the same and by another, by the same that is each time another, because the identity of a ghost is precisely the 'problem' (problema: at once question, task, program, and shield, the apotropaic armour: armour against armour, one helmet/Hamlet fascinated by the other [un heaume par l'autre fasciné], a duel under visors). ${ }^{19}$

Joyce recognized as his ghost the spectre of Shakespeare himself, the unhappy happy genius and hero of banishment, if when he looks at himself in the magical mirror, he sees the reflection of the wounded person, Shakespeare the cuckold, ravished, wearing antlers, who crosses the Dublin Library with Stephen and mingles with Bloom in the hallucinations of 'Circe'. As for Derrida, he adopts as his shemblable this double problematic Hamlet, the one who dictates his letter to the son and the one who replies to the father, each father and son of the other, each fighting for the other, under the same helmet, under the same word, under the same name. Like/as Hamlet Hamlet, he convokes the revenant that he conjures away: Come so that I may chase you!

Come so that I may chase you! You hear! I chase you. I pursue you. I run after you to chase you away from here. I will not leave you alone. And the ghost does not leave its prey, namely, its hunter. It has understood instantly that one is hunting it just to hunt it, chasing it away only so as to chase after it. Specular circle: one chases after in order to chase away, one pursues, sets off in pursuit of someone to make him flee, but one makes him flee, distances him, expulses him so as to go after him again and remain in pursuit. One chases someone away, kicks him out the door, excludes him, or drives him away. But it is in order to chase after him, seduce him, reach him, and thus keep him close at hand. One sends him far away so as to spend one's life, and for as long a time as possible, coming close to him again. The long time is here the time of this distance hunt (a hunt for distance, the prey, but also a hunt with distance, the lure). ${ }^{20}$

One sends him far away so as to spend one's life, I pick up [relève] this equivocal 'sentence', availing myself of the play with the comma which Derrida resorts to when he practises segmentation and thus 
packs a double meaning [il fait coup double], so that in French two utterances change places, one being the shadow, the ghost, and the contrary of the other. I pick up this sentence, therefore, 1) to bring out the hauntological mode of Derrida's writing, but also 2) to show how, thanks to the secret powers of discourse, to the resources of the idiom, the twists and turns of syntax, one can read here the famous plot fomented by Claudius against Hamlet, with Rosencrantz and Guildenstern as his notorious associates: one sends the prince-toomany far away, 'for thine especial safety' (Act 4, scene 3), so as to 'spend his life' so that (his) life is spent and, with it, the desire to live and avenge himself, it is in this scene of an unheard-of audacity that the Derridean - Shakespearean - theme of the distancing of the self, of expedition, dispatching, while being elaborated in the darkest and most crooked of ways, is made to run alongside, is accompanied by Hamlet's fabulous - deliberate — slip of the tongue:

King. The bark is ready, and the wind at help,

The associates tend, and every thing is bent

For England.

Ham. For England!

King. Ay, Hamlet.

Ham. Good.

King. So is it, if thou knew'st our purposes.

Ham. I see a cherub that sees them. But, come; for England! Farewell, dear mother.

King. Thy loving father, Hamlet.

Ham. My mother: father and mother is man and wife, man and wife is one flesh, and so, my mother. Come, for England!

(Hamlet, 4.3.47-56)

True, when Derrida mimes this extraordinary hunt of the Snark in almost comical terms: Come so that I may chase you!', in a stylistic register parodying, and how profoundly, at once the antics of a Punch and Judy show and the traffic of the unconscious, he does not have this scene from Hamlet in mind. But if it allows itself to be glimpsed behind the curtain, it is because, in Spectres of Marx as in Hamlet, the two great 'chance analysts' [de fortune] have descended into the same infernal theatre where parents and children kill one another's mutual 
flesh, in order to observe the most cruel hatred, that which is passed on in family ties.

\section{It ghosts: The surplus scare [trop-peur] of Jacques Derrida 'with the thing in question [...] one scares oneself too much $^{21}$}

The scene of writing is under the cloak [sous cape]. Why does Derrida underline in a note (Spectres of Marx, pp. 195-6), that is to say, as a mole, pioneering and burrowing under the text of a chapter most laden with ghosts, revenants and company, titled 'Apparition of the inapparent' - why does the mole Jacques Derrida underline subtextually [souligne-t-il, soutexte-t-il] this symptom or sign picked up [relevé] in Freud which he has just begun to analyse, that is to say, Freud's complex behaviour as he busies himself round the concept of Unheimlichkeit, and confesses without confessing that one ought to have started searching with the Unheimlichkeit, which he did not do. Why does the detective, or the Poesque analyst, J. Derrida Dupin, reveal, but in a low key, furtively in small print, the result of his observation he carries out on the subject of the more or less self-analysing, analysed Analyst? The file, the staging of this apparently inapparent enquiry, the setting (as an) aside, deserves consideration:

Present existence or essence has never been the condition, object, or the thing of justice. One must constantly remember that the impossible ('to let the dead bury their dead') is, alas, always possible. One must constantly remember that this absolute evil (which is, is it not, absolute life, fully present life, the one that does not know death and does not want to hear about it) can take place, One must constantly remember that it is even on the basis of the terrible possibility of this impossible that justice is desirable: through but also beyond right and law.

$$
\text { [...] }
$$

If he loves justice at least, the 'scholar' of the future, the 'intellectual' of tomorrow should learn it and from the ghost. He should learn to live by learning not to make conversation with the ghost but how to talk with him, with her, how to let them speak or how to give them back speech, even if it is in oneself, in the other, 
in the other in oneself: they are always there, spectres, even if they do not exist, even if they are no longer, even if they are not yet. They give us to rethink the 'there' as soon as we open our mouths, even at a colloquium and especially when one speaks there in a foreign language:

Thou art a scholar; speak to it, Horatio. ${ }^{22}$

If, when reading these pages from Spectres of Marx, one took care to watch them, to notice their tableau, their composition, one would perceive fairly quickly many a symptomatic fold. Substitution, delegation, mistaken identities work their equivocal effect 'under the cloak'.

(One day I will add to this chase a note on the homophones Cap (cape, heading) and Cape (cape, cloak) and their fate in Derrida's text. As is well known, he has privileged the Cap in more than one text, extending his powerful reflection to the whole semantics derived from Cap, Caput (head), Capital, etc. As for the cape/cloak which copes the cape/heading [la cape qui chape le cap], and which enjoys an immense idiomatic fortune in the French literary archive in the phrase sous cape, rire sous cape (to laugh up one's sleeve), he has adorned himself little with it. And yet, if there ever were a thinker who laughed up the sleeve of his cape or cloak, it is him indeed. More anon.)

Back to my vantage point.

One can thus see here 1) Derrida detecting a trace of embarrassment, half-confession, denial, in Freud (let's not forget that it is Marx that Derrida is mainly busy with in this volume. Under Marx Freud, under the cloak Derrida. Each pointing at the blind spot in the other, as will have been noted quickly) 2) Making the most of this moment of self-shaking in Freud, he, Derrida, under the cloak of a mole, quickly and briskly develops the self-analysis sketched out, then suspended by Freud. Derrida completes it. Twice: once in a footnote, laughing at Freud's contradictory propositions on the Unheimlichkeit and literature, he declares he keeps for himself the subject of Hamlet whose store of spectral powers Freud will have failed to take the measure of. The second time in the body of the text. This is where Derrida, with soft irony, denounces Freud's decision to stop the analysis, on the pretext of preserving the serenity of analytic and 
philosophical research (cf. Spectres of Marx, pp. 173-74 and n. 38, pp. 195-96).

- One should not scare oneself too much, Freud would say, it is not good for the epistemological spirit.

Lady $M$. These deeds must not be thought

After these ways; so, it will make us mad.

(Macbeth, 2.2.34-35)

Where Freud leaves off and, out of good or bad faith, justifies prudence, is where Derrida resumes and revives the anxiety, a light in his darkness. One must know how to go too far, dare to be scared too much. It is this way that the ethical and the political must orient themselves so as to open onto the future-to-come [a-venir].

One must not be afraid of being afraid of ghosts, he gives us to understand. While shaking with fear, that is to say, with heart, one must allow oneself to be led with them towards the still unthought, 'grant them the right', out of a concern for justice, says Derrida (cf. Spectres of Marx, p. 176, quoted before).

The ghost by death, the paradigmatic prototype of the ghost by absence, by repression, by invisibilization. Here is in the same region of the text another figure for it, all too familiar in our times, that of the clandestine immigrant, of the turned-back refugee, of the undocumented [sans-papier]. That one belongs to the border:

He belongs to a time of disjunction, to that 'time is out of joint' in which is inaugurated, laboriously, painfully, tragically, a new thinking of borders, a new experience of the house, the home, and the economy. Between earth and sky. One should not rush to make of the clandestine immigrant an illegal alien or, what always risks coming down to the same thing, to domesticate him. To neutralize him through naturalization. To assimilate him so as to stop frightening oneself (making oneself fear) with him. He is not part of the family, but one should not send him back, once again, him too, to the border. ${ }^{23}$

One will have recognized him: speaking here about the destiny of the inadmissible immigrant, that is to say, of Marx, that is to say, of 
Moses or of Mahomet, Derrida is speaking about himself, and in the disjunction of times, more than once / no more of one time [plus d'une fois]: before life as such and before death as such, retrospectively and premonitorily.

\section{Translated by Laurent Milesi}

\section{Notes}

'Shakespeare Ghosting Derrida' is the first part of a lecture given at Cardiff University in September 2007, on the occasion of a one-day conference on 'Shakespeare and Derrida'. The full text of the original lecture, titled 'Shakespeare and Jacques Derrida: The Gift of the Ghost, or The Beaver and The Mole', was translated by Laurent Milesi from the still unpublished French original. This translation, together with subsequent editorial notes, was slightly revised for publication here.

${ }^{1}$ Originally published in Quinzième Assises de la Traduction Littéraire (Arles 1998) (Arles: Actes Sud, 1999), 21-48; 'What Is a "Relevant" Translation?', trans. Lawrence Venuti, Critical Inquiry 27 (Winter 2001), 174-200.

2 James Joyce, Finnegans Wake (London, Faber, 1975 [1939]), 489.28: 'my shemblable! My freer!', a punning distortion of Charles Baudelaire's famous address to the reader in Les Fleurs du mal: '- mon semblable, - mon frère!', with Shem, one of the two brother-sons in Joyce's book. - Tr.

3 Derrida, 'What Is a "Relevant" Translation?', 186; trans. modified.

${ }^{4}$ The second part of an interview, originally published in Digraphe, no. 11 (1977), 83-121, and subsequently collected in Jacques Derrida, Points de suspension. Entretiens, ed. Elisabeth Weber (Paris, Galilée, 1992), 37-81; Points... Interviews, 1974-1994, ed. Elisabeth Weber, trans. Peggy Kamuf et al. (Stanford, Stanford University Press, 1995), 30-77.

5 Derrida, 'What Is a "Relevant" Translation?', 175; trans. modified.

6 (Paris: Galilée, 2000); 'Psychoanalysis Searches the States of Its Soul: The Impossible Beyond of a Sovereign Cruelty', Without Alibi, ed., trans., and intr. Peggy Kamuf (Stanford, Stanford University Press, 2002), 238-80.

7 Jacques Derrida, 'Ulysses Gramophone: Hear say yes in Joyce', trans. Tina Kendall, with emendations by Shari Benstock, James Joyce: The Augmented Ninth. Proceedings of the Ninth International James Joyce Symposium, Frankfurt 1984, ed. Bernard Benstock (Syracuse, N.Y., Syracuse University Press, 1988), 47 (pp. 27-75).

8 Derrida, 'Ulysses Gramophone', 48. 
9 Jacques Derrida, 'Aphorism Countertime', trans. Nicholas Royle, Acts of Literature, ed. Derek Attridge (New York and London, Routledge, 1992), 420 (pp. 414-33).

${ }^{10}$ Derrida, 'What Is a "Relevant" Translation?', 198; trans. modified.

11 Jacques Derrida, The Post Card: From Socrates to Freud and Beyond, trans., with an Introduction and Additional Notes by Alan Bass (Chicago and London, Chicago University Press, 1987), 292-337.

12 This refers to the year when Derrida, aged eleven, was expelled from school overnight, following the Rector's overzealous application of exclusionary measures against Jewish children. See Geoffrey Bennington's 'Curriculum Vitae' in Geoffrey Bennington and Jacques Derrida, Jacques Derrida, trans. Geoffrey Bennington (Chicago and London, University of Chicago Press, 1993), 326. - Tr.

13 James Joyce, Ulysses. A Critical and Synoptic Edition, Prepared by Hans Walter Gabler with Wolfhard Steppe and Claus Melchior, 3 vols. (New York and London, Garland, 1986), vol. 1, 9:472-3, 479-81. Here Cixous silently substitutes the ancient North African city of Hippo, where Saint Augustine died, for Joyce's original Elsinore in Stephen Dedalus' musings about Hamlet. - Tr.

${ }_{14}$ This refers to Jacques Derrida's mother, whose full name was Sultana Esther Georgette Safar. - Tr.

15 The title of a book by Derrida (Paris, Galilée, 2003), whose original title was The Work of Mourning, ed. Pascale-Anne Brault and Michael Naas (Chicago and London, University of Chicago Press, 2001). - Tr.

16 Jacques Derrida, Spectres of Marx: The State of the Debt, the Work of Mourning, and the New international, trans. Peggy Kamuf, intr. Bernd Magnus and Stephen Cullenberg (London, Routledge, 1994), 77; trans. modified.

${ }^{17}$ Cf. Maurice Blanchot, The Instant of My Death / Jacques Derrida, Demeure: Fiction and Testimony, trans. Elizabeth Rottenberg (Stanford, Stanford University Press, 2000), 46-7.

${ }_{18}$ Derrida, Spectres of Marx, 139-40.

19 Derrida, Spectres of Marx, 139-40; trans. modified in order to bring out the nearhomophony in French on heaume and homme. - Tr.

${ }^{20}$ Derrida, Spectres of Marx, 140; trans. modified.

${ }_{21}$ Derrida, Spectres of Marx, 173.

${ }_{22}$ Derrida, Spectres of Marx, 175-6.

23 Derrida, Spectres of Marx, 174. 